\title{
Protein Kinase C-Binding Protein NELL1
}

National Cancer Institute

\section{Source}

National Cancer Institute. Protein Kinase C-Binding Protein NELL1. NCI Thesaurus. Code C128936.

Protein kinase C-binding protein NELL1 (810 aa, $90 \mathrm{kDa}$ ) is encoded by the human NELL1 gene. This protein is involved in the modulation of osteoblast cell growth and differentiation. 